\title{
Hydraulic traits and tree-ring width in Larix sibirica Ledeb. as affected by summer drought and forest fragmentation in the Mongolian forest steppe
}

\author{
Elmira Khansaritoreh ${ }^{1} \cdot$ Bernhard Schuldt $^{1} \cdot$ Choimaa Dulamsuren $^{1}$ \\ Received: 28 July 2017 / Accepted: 29 January 2018 / Published online: 8 March 2018 \\ (C) INRA and Springer-Verlag France SAS, part of Springer Nature 2018
}

\begin{abstract}
- Key message Wood-anatomical traits determining the hydraulic architecture of Larix sibirica in the drought-limited Mongolian forest steppe at the southern fringe of the boreal forest respond to summer drought, but only weakly to variations in microclimate that depend on forest stand size.

- Context Siberian larch (L. sibirica Ledeb.) is limited by summer drought and shows increasing mortality rates in the Mongolian forest steppe. The climate sensitivity of stemwood formation increases with decreasing forest stand size. The trees' hydraulic architecture is crucial for drought resistance and thus the capability to deal with climate warming.

- Aims We studied whether hydraulic traits were influenced by temporal or forest size-dependent variations in water availability and were related to tree-ring width.

- Methods Hydraulic traits (tracheid diameter, tracheid density, potential sapwood area-specific hydraulic conductivity) of earlywood were studied in stemwood series of 30 years (1985-2014) and were related to climate data. Tree-ring width was measured for the same period. Trees were selected in stands of four different size classes with increasing drought exposure with decreasing stand size.

- Results Tracheid diameters and hydraulic conductivity decreased with decreasing late summer precipitation of the previous year and were positively correlated with tree-ring width. Forest stand size had only weak effects on hydraulic traits, despite known effects on stemwood increment.

- Conclusion Decreasing tracheid diameters and thus hydraulic conductivity are a drought acclimation of $L$. sibirica in the Mongolian forest steppe. These acclimations occur as a response to drought periods but are little site-dependent with respect to stand size.
\end{abstract}

Keywords Wood anatomy $\cdot$ Tracheid diameters $\cdot$ Hydraulic conductivity $\cdot$ Tracheid density $\cdot$ Boreal forest $\cdot$ Forest fragmentation

Handling Editor: Thomas Wohlgemuth

Contribution of the co-authors

EK, BS, and DC designed the study. EK and DC conducted field work. EK, BS, and DC worked on samples, analyzed data, and wrote the paper.

Electronic supplementary material The online version of this article (https://doi.org/10.1007/s13595-018-0701-2) contains supplementary material, which is available to authorized users.

Choimaa Dulamsuren

dchoima@gwdg.de

Elmira Khansaritoreh

elmira.kh@gmail.com

Bernhard Schuldt

bschuld2@gwdg.de

1 Plant Ecology, Albrecht von Haller Institute for Plant Sciences, Georg August University of Göttingen, Untere Karspüle 2, 37073 Göttingen, Germany

\section{Introduction}

Stem wood formation is highly sensitive to variations in climate. In boreal forests, annual stem increment is usually limited by either low summer temperature or summer drought (Tei et al. 2017). Climate warming increasingly converts temperature-limited forests into drought-limited ones (Buermann et al. 2014). While the climatic limitation of stem increment is well studied and forms the basis for dendrochronology, effects on wood-anatomical features and trade-offs between tree-ring width and xylem anatomy are less well studied in boreal forests. Climate exerts effects not only on tree-ring width, but also on the occurrence of intra-annual wood-anatomical features (Yasue et al. 2000; Wang et al. 2002; De Grandpré et al. 2011); this includes traits of the 
xylem anatomy that are relevant for water transport (Eilmann et al. 2009; Fonti and Babushkina 2015).

Conduits for water transport should be wide to ensure high hydraulic conductivity, since the maximum flow rate depends on the conduit radius in the fourth power, according to HagenPoiseuille's law for the transport of fluids in cylindrical pipes (Tyree and Zimmermann 2002). Water transport is in turn the prerequisite for $\mathrm{CO}_{2}$ assimilation. However, large conduit diameters increase the cavitation risk, which can result in hydraulic failure and ultimately tree mortality (Hacke et al. 2001; Cochard et al. 2004; Poyatos et al. 2013). The relationship between conduit diameter and embolism resistance is thought to be an indirect one that depends on pit structure (Sperry et al. 2006; Delzon et al. 2010). Trees show inter-annual and sitedependent plasticity in their hydraulic architecture to take up and transport water efficiently under moist conditions, but to reduce the risk of cavitation during drought (Poyatos et al. 2007; Bryukhanova and Fonti 2013). Relevant parameters that can be adapted to water supply include conduit diameters, conduit density, and the resulting hydraulic conductivity (Tyree and Zimmermann 2002; Tyree 2003; Pittermann et al. 2006). Dry conditions are usually associated with low hydraulic conductivity (Hacke and Sperry 2001; Sperry et al. 2006). Hydraulic conductivity results from the combination of conduit diameters and tracheid numbers in the sapwood.

The southernmost boreal forests in Inner Asia are mostly strongly drought-limited (Dulamsuren et al. 2010, 2013; Liu et al. 2013), although also temperature-limited forests occur especially at high elevations (Jacoby et al. 1996; D’Arrigo et al. 2000). The Mongolian forest steppe represents a widely drought-limited part of the boreal forest in this region, which is strongly dominated by Siberian larch (Larix sibirica). Here, Chenlemuge et al. (2015a, b) demonstrated increasing tracheid diameters and increasing hydraulic conductivity with increasing moisture availability.

Forests in the Mongolian forest steppe are naturally fragmented, because they are largely limited to north-facing mountain slopes, which represent, aside from riverine habitats, the moistest sites in the landscape. Forest fragmentation is additionally promoted as the result of logging, livestock grazing, as well as drought- and fire-related forest declines (Khishigjargal et al. 2013; Lkhagvadorj et al. 2013; Dulamsuren et al. 2014). At present, Mongolia belongs to the countries with the highest decreases in forest cover loss (Hansen et al. 2013).

Studying the annual stem increment of L. sibirica in forest stands of different size, Khansaritoreh et al. (2017) found that the sensitivity of stemwood production to summer drought increased with decreasing stand size, because maximum air temperatures increased and relative humidity decreased with decreasing stand size. This means that anthropogenic forest fragmentation exacerbates the detrimental impact of global warming on tree growth in a region, which is exposed to temperature increases far above the global average (IPCC
2013) and where L. sibirica widely shows growth depressions, failure of regeneration, and increased mortality (Dulamsuren et al. 2010; Liu et al. 2013).

Since Chenlemuge et al. (2015a, b) established trade-offs between tree-ring width, tracheid diameter, tracheid density, and hydraulic conductivity in L. sibirica, we were interested in the question whether forest stand size also left an imprint in the tree's hydraulic architecture. Moreover, whereas several studies on the climate response of annual stem increment from the Inner Asian forest-steppes are published (D'Arrigo et al. 2000; De Grandpré et al. 2011; Dulamsuren et al. 2011, 2013), little is known on climate effect on hydraulic traits in L. sibirica. Therefore, we were also generally interested on the climate dependency of tracheid diameter, tracheid density, and hydraulic conductivity irrespective of stand size. The objective of our study was to test the hypotheses that (1) drought years cause signals in the trees' hydraulic architecture in addition to their effect on tree-ring width; (2) tracheid diameters that are crucial for shaping hydraulic conductivity are correlated with tree-ring width; and (3) tracheid diameter, tracheid density, and hydraulic conductivity vary in dependence of stand size.

\section{Materials and methods}

\subsection{Study area}

The study was conducted in the Mongolian forest steppe, which is the ecotone between the southernmost Siberian taiga and the Central Asian steppe grasslands. Field work was carried out in the Khangai Mountains in Zavkhan province near Tosontsengel ( $48^{\circ} 45^{\prime} \mathrm{N}, 98^{\circ} 16^{\prime} \mathrm{E}, 1700 \mathrm{~m}$ a.s.l.), ca. $630 \mathrm{~km}$ W of Ulan Bator and $550 \mathrm{~km} \mathrm{SW}$ of Lake Baikal, in August 2014. The Khangai Mountains represent a major mountain range of central and western Mongolia that constitutes much of Mongolia's forest steppe area. The forest steppe landscape consists of mosaics of Siberian larch forest islands occurring at variable size on north-facing slopes and grasslands covering south-facing slopes and dry valleys. Mongolia's boreal forests (ca. 73,800 km²; Dulamsuren et al. 2016) are strongly dominated by Siberian larch (Larix sibirica Ledeb.), which occupies $80 \%$ of the forest area (Tsogtbaatar 2004). Siliceous rock, including granite and metamorphic rock (e.g., schist), is the prevailing bedrock in our study region. The dominant forest soils are Cambisols and Leptosols.

\subsection{Climate in Mongolia and our study area}

The extreme continental climate of Mongolia is characterized by long cold winters, coined by the stable Siberian High Pressure Cell, and short warm summers with most rainfall in July. In most of the forest steppe region, mean annual 
temperature is below or around zero. Mean annual precipitation is approximately $200-300(-400) \mathrm{mm}$ in most of the forest steppe. Climatic data from our study area are available from 1964 (temperature) to 1968 (precipitation) according to records from Tosontsengel meteorological station. This study covers 30 years from 1985 to 2014, and in this period, mean annual air temperature was $-5.4{ }^{\circ} \mathrm{C}$ (July $15.3{ }^{\circ} \mathrm{C}$, January $31.2{ }^{\circ} \mathrm{C}$ ). Mean annual precipitation amounted to $232 \mathrm{~mm}$, ranging from 148 to $430 \mathrm{~mm}$. Mean growing season (MaySeptember) air temperature has increased by $0.58^{\circ} \mathrm{C}$ decade $^{-1}$ since 1985 (Fig. 1). In the growing seasons of this period, June and July showed the strongest increase in monthly temperature and a marked decrease in monthly precipitation (Fig. S1). August precipitation did not change over time, while August temperature has increased (like the mean growing season temperature) by c. $0.6 \mathrm{C} \mathrm{decade}^{-1}$.

\subsection{Study design and core sampling}

We defined four different classes (F1 to F4) of forest stand size varying from $<0.1 \mathrm{~km}^{2}$ (F1) to $>5.0 \mathrm{~km}^{2}$ (F4) (Table 1) and selected two stands per size class (Fig. S2). Elevation of the selected stands varied between 1809 and $2135 \mathrm{~m}$ a.s.l. The distance of the sampled trees to the lower forest line was between 110 and $330 \mathrm{~m}$. Forests of the different size classes were characterized by differences in
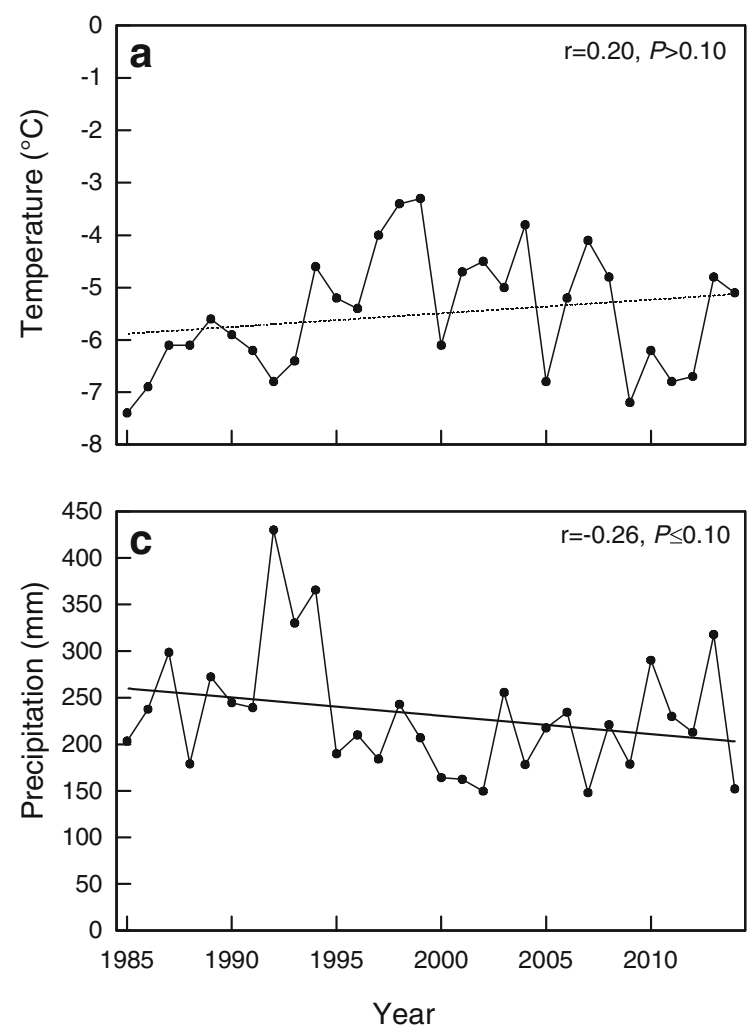

Fig. 1 Climate trends in Tosontsengel $\left(48^{\circ} 45^{\prime} \mathrm{N}, 98^{\circ} 16^{\prime} \mathrm{E}, 1700 \mathrm{~m}\right.$ a.s.1.), northwestern Mongolia, 1985-2014: a mean annual temperature, b mean microclimate and land use intensity (Khansaritoreh et al. 2017). Individual forest stands from different size classes were selected randomly based on remote-sensing analysis of forest distribution in the study region. Trees were selected in the interior of each forest stand, and geographic positions of stands were determined by GPS.

We selected five trees per stand size (in total 20 individuals, Table 1) which were intact, stout, dominant, and of similar height to eliminate competition effects. Importance of height in relation with variation in conduit diameter and hydraulic properties has been earlier shown in several studies (Ryan and Yoder 1997; Woodruff et al. 2004; Koch et al. 2004; Pennisi 2005; Ryan et al. 2006; Domec et al. 2008; Anfodillo et al. 2013). While we kept height constant, variation in diameter at breast height (DBH) had to be accepted; F1 trees had significantly higher DBH than trees from the other stand sizes (Table 1). The suitability of this procedure was later reconfirmed by our data, since we found that variation in DBH did not influence anatomical traits. For example, there was no significant correlation between DBH and tracheid diameters $(P=0.24, r=0.17)$. Non-metric multidimensional scaling (NMDS) ordination of tree-ring series results showed that our selected sample trees for anatomical studies from the individual stand size classes represented the entire stands of the same size class, because the sample trees are evenly distributed in the homogenous scatter plots (Fig. S3).
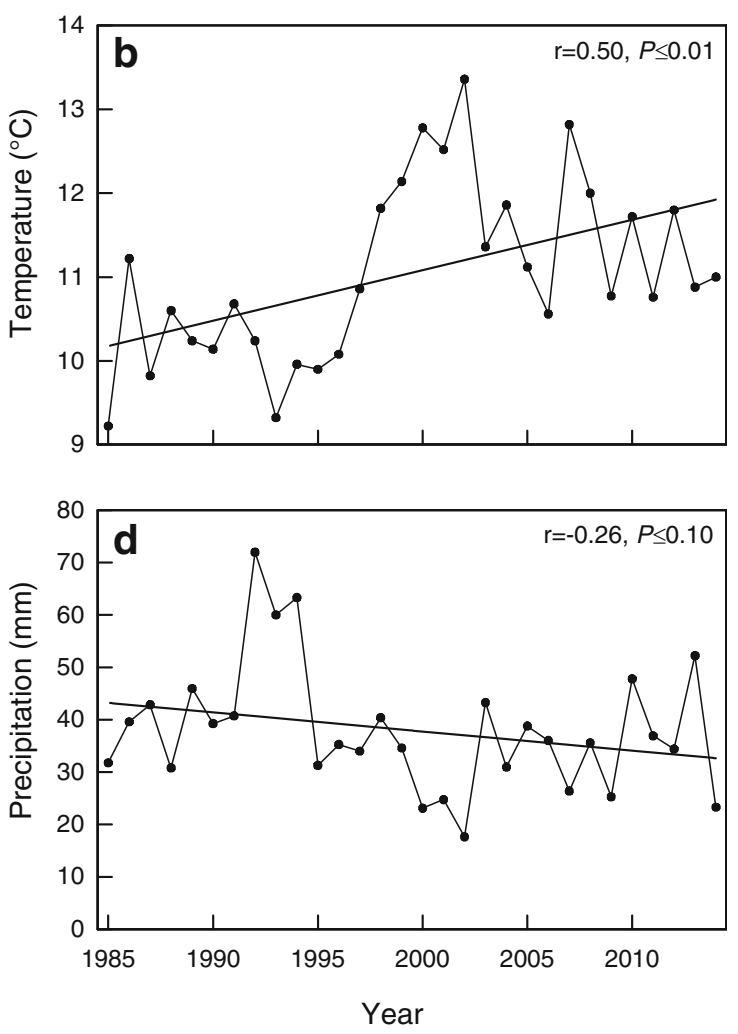

growing season temperature, $\mathbf{c}$ annual precipitation, $\mathbf{d}$ growing season precipitation 
Table 1 Main tree characteristics, mean sensitivity, and autocorrelation of tree-ring width (arithmetic mean $\pm \mathrm{SE}$ )

\begin{tabular}{lllllll}
\hline Stand size & Forest size $\left(\mathrm{km}^{2}\right)$ & Height $(\mathrm{m})$ & DBH $(\mathrm{cm})$ & Ring width $(\mathrm{mm})$ & Mean sensitivity $(\%)$ & Autocorrelation \\
\hline F1 & $<0.1$ & $20.2 \pm 1.7 \mathrm{a}$ & $57.8 \pm 4.3 \mathrm{a}$ & $0.29 \pm 0.03 \mathrm{ab}$ & $39.6 \pm 2.2 \mathrm{a}$ & $0.57 \pm 0.06 \mathrm{a}$ \\
F2 & $0.1-1.0$ & $19.3 \pm 0.8 \mathrm{a}$ & $36.9 \pm 3.7 \mathrm{~b}$ & $0.31 \pm 0.10 \mathrm{a}$ & $37.8 \pm 1.8 \mathrm{ac}$ & $0.67 \pm 0.05 \mathrm{ab}$ \\
F3 & $1.1-5.0$ & $18.4 \pm 1.0 \mathrm{a}$ & $30.4 \pm 5.8 \mathrm{~b}$ & $0.35 \pm 0.08 \mathrm{a}$ & $35.7 \pm 2.7 \mathrm{ac}$ & $0.68 \pm 0.07 \mathrm{ab}$ \\
F4 & $>5.0$ & $19.5 \pm 1.5 \mathrm{a}$ & $30.5 \pm 2.0 \mathrm{~b}$ & $0.25 \pm 0.04 \mathrm{~b}$ & $27.2 \pm 1.1 \mathrm{~b}$ & $0.82 \pm 0.03 \mathrm{~b}$ \\
\hline
\end{tabular}

Number of samples: 5 trees per stand size class. Ring width data refers to the period 1985-2014. Stand size classes with same lower case letters are not statistically significantly different (Tukey's test, $P \leq 0.05, d f_{\text {model, error }}=3,15$ )

$D B H$ diameter at breast height

A total of 40 wood cores (i.e., two cores collected in close vicinity to each other from the same side of each tree) was collected at stem breast height $(1.3 \mathrm{~m}$ height above the ground) using increment borer with an inner diameter of $5 \mathrm{~mm}$. Samples were taken parallel to the contour lines of the mountain slopes to avoid compression wood.

\subsection{Xylem anatomy analysis}

All 20 cores were stored in $70 \%$ ethanol prior to laboratory preparation. We applied two different procedures for dyeing samples based on their quality. In one procedure, the whole cores were stained (before cutting) with safranin (1\% in 50\% ethanol, Merck, Darmstadt, Germany) for 3 days followed by rinsing the samples with $70 \%$ ethanol three times while shaking for $12 \mathrm{~h}$. Subsequently, the samples were soaked in distilled water for 3 days. In a second procedure, another subsample of wood cores was only soaked in distilled water to be softened and then microsections were dyed after cutting. The quality of the results of the staining procedures is slightly variable between individual samples; therefore, we selected the wood core subsample for analysis visually for every individual sample after staining. Wood cores (produced by both procedures) were cut with a sliding microtome (G.S.L. 1, WSL Birmensdorf, Switzerland) into semi-thin transverse sections (10-15 $\mu \mathrm{m}$ thick). To reduce distortions of the samples during cutting, a solution of corn starch, water, and glycerol (Schneider and Gärtner 2013) was placed on the wood cores immediately before cutting. After cutting, starch particles were removed by washing with water and ethanol. The unstained microsections were stained with a mixture of safranin and alcine blue for 1-2 min and subsequently rinsed with water. Dehydration of microsections was done firstly with $70 \%$ ethanol and secondly with $99 \%$ ethanol. Afterwards, microsections were fixed with Euparal adhesive and dried for 10 days at $50{ }^{\circ} \mathrm{C}$. Finally, the complete microsections were photographed at $100-150 \times$ magnification using a stereomicroscope equipped with an automatic stage (SteREOV20, Carl Zeiss MicroImaging GmbH, Jena, Germany; Software: AxioVision v4.8.2, Carl Zeiss MicroImaging GmbH).
Since water transport primarily takes place in the earlywood, whereas latewood has predominantly a mechanical function (Vaganov et al. 2006; Eilmann et al. 2006), we limited our analyses to earlywood formed between 1985 and 2014 (30 years). Image analysis was performed in Adobe Photoshop CS2 9.0 (Adobe Systems, San Jose, California, USA) and ImageJ software (Wayne Rasband, National Institute of Health, Bethesda, Maryland, USA) using the particle analysis function. We measured single and cumulative tracheid lumen areas $\left(\mathrm{mm}^{2}\right)$, tracheid density (TD, in $N \mathrm{~mm}^{-2}$ ), and idealized tracheid diameters $(d$, in $\mu \mathrm{m})$ from both major (a) and minor (b) tracheid radii using the equation given by White $(1991)$ as $d=\left(\left(32(a b)^{3}\right) /\left(a^{2}+b^{2}\right)\right)^{1 / 4}$. Hydraulic mean diameter $\left(d_{\mathrm{h}}\right.$, in $\left.\mu \mathrm{m}\right)$, which puts more weight on large than small conducting vessels (Sperry et al. 1994), was calculated from $d$ as $d_{\mathrm{h}}=\sum d^{5} \sum d^{4}$. According to the Hagen-Poiseuille equation, potential sapwood area-specific hydraulic conductivity $\left(K_{\mathrm{p}}\right.$, in $\left.\mathrm{kg} \mathrm{m}^{-1} \mathrm{MPa}^{-1} \mathrm{~s}^{-1}\right)$ was calculated from the tracheid radii as $K_{\mathrm{p}}=\pi\left(\sum r^{4}\right) \rho /\left(8 \eta A_{\mathrm{xylem}}\right)$, where $\eta$ is the viscosity and $\rho$ is the density of water at $20^{\circ} \mathrm{C}$, while $A_{\text {xylem }}$ is the corresponding cross-sectional xylem area without pith and bark. In the stem wood, we analyzed a range of 63-1033 tracheids per tree ring or 5260-13,341 tracheids per complete cross section. The high variability is due to interannual variation in stem increment.

\subsection{Tree-ring analysis}

One core per sample tree was prepared (mounted on wooden strips, cut lengthwise with a microtome, and chalk added to enhance contrasts between the annual rings) for measurement of tree-ring width (TRW). TRW was measured and tree-ring data were evaluated with Time Series Analysis and Presentation (TSAP)-Win software (Rinntech, Heidelberg, Germany). We used a movable object table (Lintab 6, Rinntech) that electronically transmits shifts to a computer system equipped with TSAP-Win software to measure TRW (and the widths of earlywood and latewood separately) with a precision of $10 \mu \mathrm{m}$. All chronologies were cross-dated visually and checked for missing rings. Cross-dating accuracy was assessed by the calculation of coefficients of agreement 
('Gleichläufigkeit' [GL]) and (standard) $t$-value (Eckstein and Bauch 1969). Only tree-ring series with GL $>65 \%$ and $t>3$ were united to mean curves. The exact tree age could not be determined for all sample trees, since the center of most trees was rotten ( 14 out of 20 trees). However, we could make sure that all trees belonged to the same age class of $>160$ years. Information on mean tree age in the stand size classes F1 to F4 from our study area is available from Khansaritoreh et al. (2017, Table S1). Based on a much higher sample size of 1033 trees, that study showed a mean cambial age $( \pm$ SE) of $157 \pm 9$ years for $\mathrm{F} 1$ ( $N=176$ trees), $146 \pm 12$ years for $\mathrm{F} 2$ $(N=146), 143 \pm 13$ years for $\mathrm{F} 3(N=317)$, and $130 \pm 11$ years for F4 $(N=279)$; there was no significant difference in tree age between the stand sizes in that data set $(P \leq 0.05$, Duncan's multiple range test). Representativeness of our sample trees for the trees of the same age class from the studied forest stands was controlled by NMDS. For NMDS, we used a larger data set of all $>160$-year old trees from $400-\mathrm{m}^{2}$ plots in the studied forests that was available from Khansaritoreh et al. (2017). Any correlation of anatomical traits with TRW was made with complete TRW, which was closely correlated with earlywood width $(r=0.99, P \leq 0.001)$. The expressed population signal (EPS) was calculated using Arstan software (Cook and Holmes 1984) to quantify how well our tree-ring series represented the stem increment dynamics of the studied stands. We accepted a given tree-ring series as representative for the whole stand when EPS $>0.85$ (Wigley et al. 1984).

\subsection{Climate-response analysis}

Climate-response analysis was conducted separately for each tree using monthly means of temperature and monthly sums of precipitation from 1985 to 2014 to quantify the influence of current and prior year's climate on the tree-ring index and $d$. Since we knew about an intensive fire in the study area in 1996 that produced a strong growth anomaly in 1997, we removed that year from our analysis to focus on the effect of climate. This was done to exclude immediate effects of fire in the sampled stands; however, it should be noted that lagged effects and competition effects from any other disturbance influenced the analysis like in any other climate-response

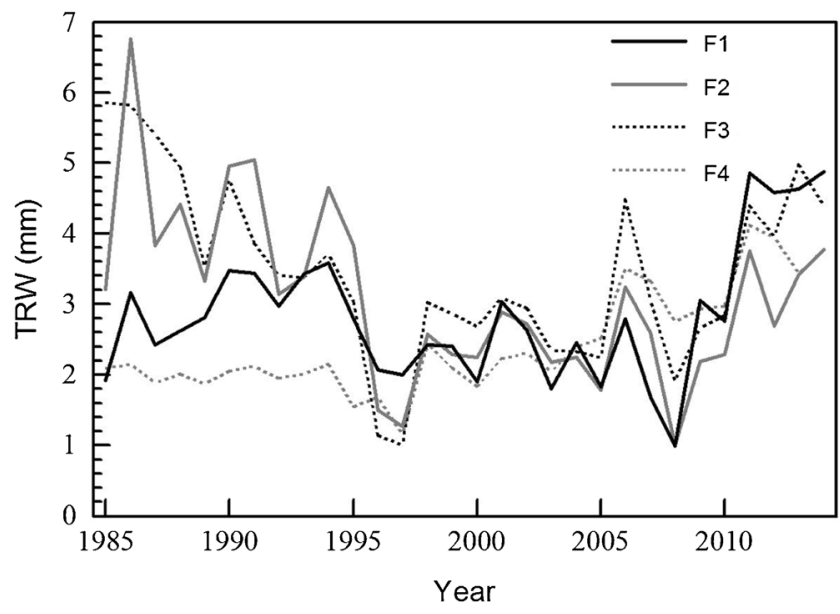

Fig. 2 Tree-ring chronologies of $L$. sibirica from the stand size classes F1 $\left(<0.1 \mathrm{~km}^{2}\right), \mathrm{F} 2\left(0.1-1 \mathrm{~km}^{2}\right), \mathrm{F} 3\left(1.1-5 \mathrm{~km}^{2}\right)$, and F4 $\left(>5 \mathrm{~km}^{2}\right)$ for the period of 1985-2014

analysis. For the climate-response analysis, the individual tree-ring series were standardized in order to remove any age-related trends. Standardization was applied, although it has only a limited effect on the results in the short time span of only 30 years included in our analysis. We used a 32-year cubic spline function with a 50\% frequency response (Cook and Kairiukstis 1990) for indexation of TRW data. We did not attempt any standardization for $d$, since we exclude the first years of growth with considerable tracheid dimension increase (Carrer et al. 2015).

Based on the monthly temperature and precipitation data and latitude of our study site, we calculated potential evapotranspiration (PET) after Thornthwaite (1948). PET was used to calculate the standardized precipitation-evapotranspiration index (SPEI) on a monthly resolution using version 1.6 of the R package "SPEI" (Vicente-Serrano et al. 2010). To find the shortest drought episodes, we selected SPEI1 (resolution of only 1 month), because drought-sensitive tree species on shallow soils may be affected by short drought periods (Fonti and Babushkina 2015).Year-to-year variability of tree-ring width was expressed as mean sensitivity, which was calculated as the difference in TRW of two consecutive years divided by the mean TRW of these years. First-order autocorrelation analyzing the connection between the increment in two consecutive years
Table 2 Anatomical parameters averaged over the period from 1985 to 2014 (arithmetic mean \pm SE)

\begin{tabular}{lllll}
\hline Stand size & $d(\mu \mathrm{m})$ & $d_{\mathrm{h}}(\mu \mathrm{m})$ & $\mathrm{TD}\left(N \mathrm{~mm}^{-2}\right)$ & $K_{\mathrm{p}}\left(\mathrm{kg} \mathrm{m}^{-1} \mathrm{MPa}^{-1} \mathrm{~s}^{-1}\right)$ \\
\hline F1 & $29.4 \pm 0.4 \mathrm{a}$ & $37.9 \pm 0.4 \mathrm{a}$ & $610 \pm 21 \mathrm{a}$ & $18.7 \pm 0.4 \mathrm{a}$ \\
F2 & $29.9 \pm 0.9 \mathrm{a}$ & $38.1 \pm 1.0 \mathrm{a}$ & $620 \pm 42 \mathrm{a}$ & $19.6 \pm 0.9 \mathrm{ac}$ \\
F3 & $25.3 \pm 1.7 \mathrm{~b}$ & $32.8 \pm 2.3 \mathrm{~b}$ & $787 \pm 115 \mathrm{~b}$ & $13.1 \pm 2.3 \mathrm{~b}$ \\
F4 & $31.2 \pm 0.8 \mathrm{c}$ & $39.3 \pm 1.2 \mathrm{c}$ & $548 \pm 28 \mathrm{c}$ & $20.2 \pm 1.6 \mathrm{c}$ \\
\hline
\end{tabular}

Tracheid diameter $(d)$, hydraulically weighted mean tracheid diameter $\left(d_{\mathrm{h}}\right)$, tracheid density (TD), potential sapwood area-specific hydraulic conductivity $\left(K_{\mathrm{p}}\right)$. Stand size classes with same lower case letters are not statistically significantly different (Tukey's test results, $P \leq 0.05, d f_{\text {model, error }}=3,596$ ) 
was calculated as a measure of the tree's physiological buffering capacity (Fritts 1976). Mean sensitivity and first-order autocorrelation were calculated from raw TRW data for the period from 1985 to 2014. Pointer years were calculated using the "PointRes" package in R (van der Maaten-Theunissen et al. 2015) to obtain information on climatically driven event years that might have influenced wood anatomy (Schweingruber et al. 1990). Since our data set of 20 trees was too small for calculating pointer years, we included data of $1280 \mathrm{~L}$. sibirica trees within the same study area (Khansaritoreh et al. 2017).

\subsection{Data processing and statistical analysis}

Arithmetic means \pm standard errors (SE) are given throughout the paper. Wood-anatomical and hydraulic data from the stem samples were first averaged for individual tree rings and then averaged (for each year) over the five trees of each stand size class. Data were tested for normality using the Shapiro-Wilk test. One-way analysis of variance (ANOVA) was combined with Tukey's post hoc test to find significant differences between stand size classes. To remove the age effect from time series, we used the R-package 'Dendrochronology Program Library in R' (dplR) 1.5.5 (Bunn 2008). Multiple regression analysis was used to quantify the response of the tree-ring index and $d$ to climate. Kernel density estimation (KDE)
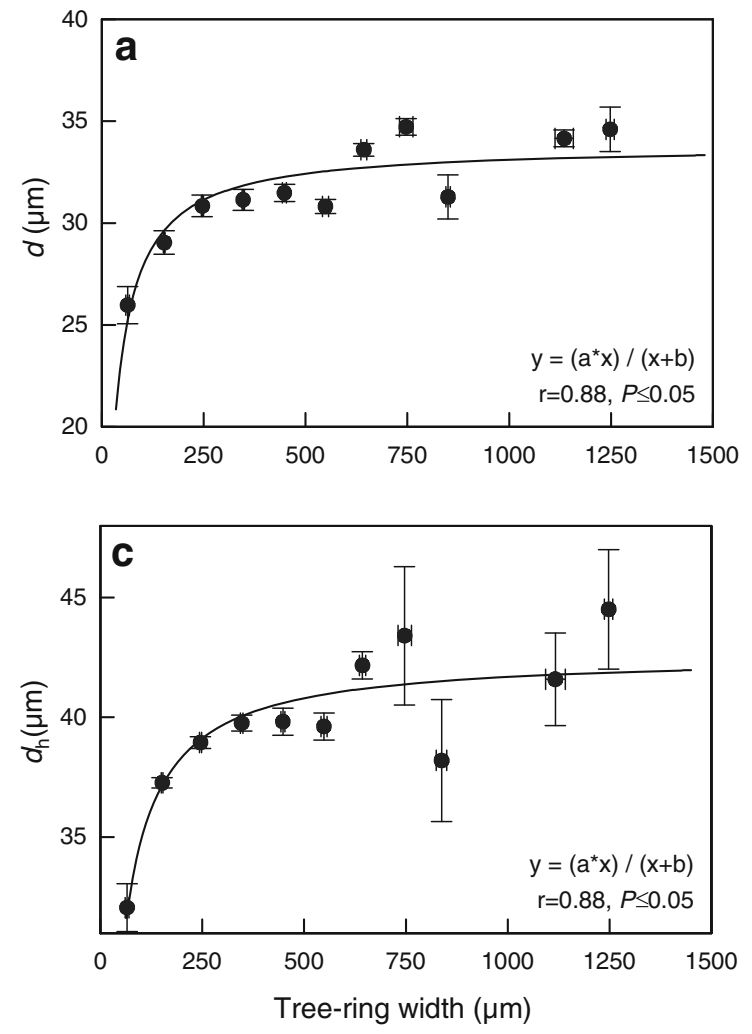

Fig. 3 a Tracheid diameter (d), b tracheid density (TD), c hydraulically weighted mean tracheid diameter $\left(d_{\mathrm{h}}\right)$, and $\mathbf{d}$ potential sapwood area- was calculated for $d$ of all samples grouped by the SPEI of the prior August, because precipitation of this month showed the most significant correlation with $d$. The NMDS was calculated using PAST 3.15 software (Ø. Hammer, Natural History Museum, University of Oslo, Norway). Correlation coefficients were calculated in linear and non-linear fits. If not mentioned otherwise, statistical analyses were carried out in $\mathrm{R}$ software (R Development Core Team).

\section{Results}

\subsection{Hydraulic conductivity and anatomical traits}

Mean diameters $(d)$ and hydraulically weighted mean diameters $\left(d_{\mathrm{h}}\right)$ of tracheids as well as the theoretical sapwood area-specific hydraulic conductivity $\left(K_{\mathrm{p}}\right)$ were higher in the largest (F4) than in the smallest forest stands (F1; Table 2). Tracheid density was lower in the F4 than the F1 stands. Nevertheless, there was no consistent trend for constant changes of these parameters with increasing forest stand size from F1 to F4. There were many inter-annual fluctuations in time series of anatomical traits $\left(d, d_{\mathrm{h}}, \mathrm{TD}\right.$, $K_{\mathrm{p}}$ ) in all forest stand sizes (Fig. S4). Any linear temporal trends for $d, d_{\mathrm{h}}, \mathrm{TD}$, and $K_{\mathrm{p}}$ were absent, except for an
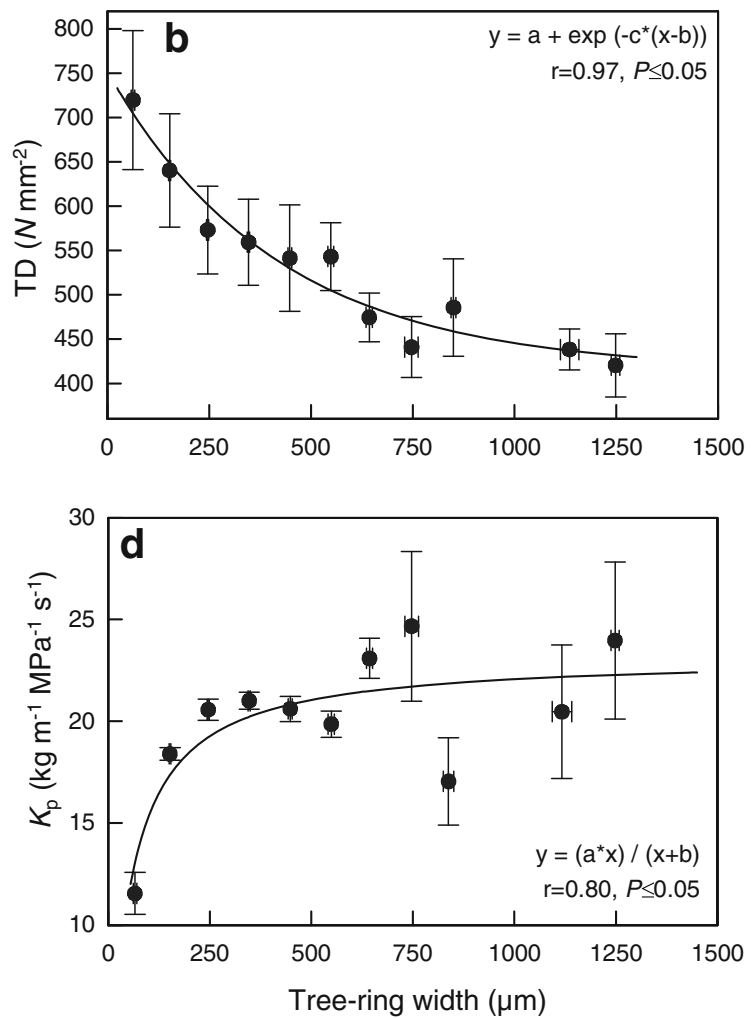

specific hydraulic conductivity $\left(K_{\mathrm{p}}\right)$ versus tree-ring width (TRW, pooled in classes of $100 \mu \mathrm{m})$. Bars indicate $\mathrm{SE}$ 
increase of $d(P<0.001), d_{\mathrm{h}}(P=0.003)$, and $K_{\mathrm{p}}(P=$ $0.001)$ and a decrease of TD $(P<0.001)$ over time in F4.

\subsection{Radial stem wood increment and stands size}

Mean tree-ring width (TRW) for the period between 1985 and 2014 ranged from 0.25 to $0.35 \mathrm{~mm}$ and did not reveal any consistent trend for increase or decrease with forest stand size (Fig. 2, Table 1). For the 20 sample trees, EPS reached 0.89 in 1895, which is long before our study interval from 1985 to 2014. Mean sensitivity decreased and first-order autocorrelation increased with forest stand size (Table 1). Tracheid diameter $\left(d, d_{\mathrm{h}}\right)$ and $K_{\mathrm{p}}$ increased with increasing TRW, whereas tracheid density (TD) decreased with TRW (Fig. 3).

\subsection{Climate response and tracheid size variation with summer drought}

Climate-response analysis revealed correlations of the treering index and the hydraulic traits with the precipitation of the previous year (Table 3). The August precipitation of the previous year was nearly consistently correlated with the treering index, $d$, and $d_{\mathrm{h}}$ (positive correlations) as well as with TD (negative correlations). $K_{\mathrm{p}}$ as a value derived from $d$ was only significant at $P \leq 0.05$ in the smallest forests of the size classes F1 and F2. June precipitation of the previous year was positively correlated with the tree-ring index in all except the largest forests (F1 to F3), but was only sporadically correlated with the hydraulic parameters. The frequency distributions of $d$ in dependence of previous year's August SPEI also

Table 3 Response of the tree-ring index, tracheid diameter $(d)$, hydraulically weighted mean tracheid diameter $\left(d_{\mathrm{h}}\right)$, tracheid density (TD), and potential sapwood area-specific hydraulic conductivity $\left(K_{\mathrm{p}}\right)$ of Larix sibirica trees from different stand size classes to monthly temperature and precipitation of the year of and the year prior to tree ring formation

\begin{tabular}{|c|c|c|c|c|c|c|c|c|c|c|c|c|c|c|c|c|c|c|c|}
\hline \multicolumn{7}{|c|}{ Temperature } & \multicolumn{13}{|c|}{ Precipitation } \\
\hline \multicolumn{6}{|c|}{ Prior year } & \multirow{2}{*}{$\begin{array}{l}\text { Current year } \\
4\end{array}$} & \multicolumn{9}{|c|}{ Prior year } & \multicolumn{4}{|c|}{ Current year } \\
\hline 3 & 4 & 5 & 6 & 7 & 8 & & 3 & 4 & 5 & 6 & 7 & 8 & 10 & 11 & 12 & 2 & 3 & 5 & 6 \\
\hline
\end{tabular}

Tree-ring index:

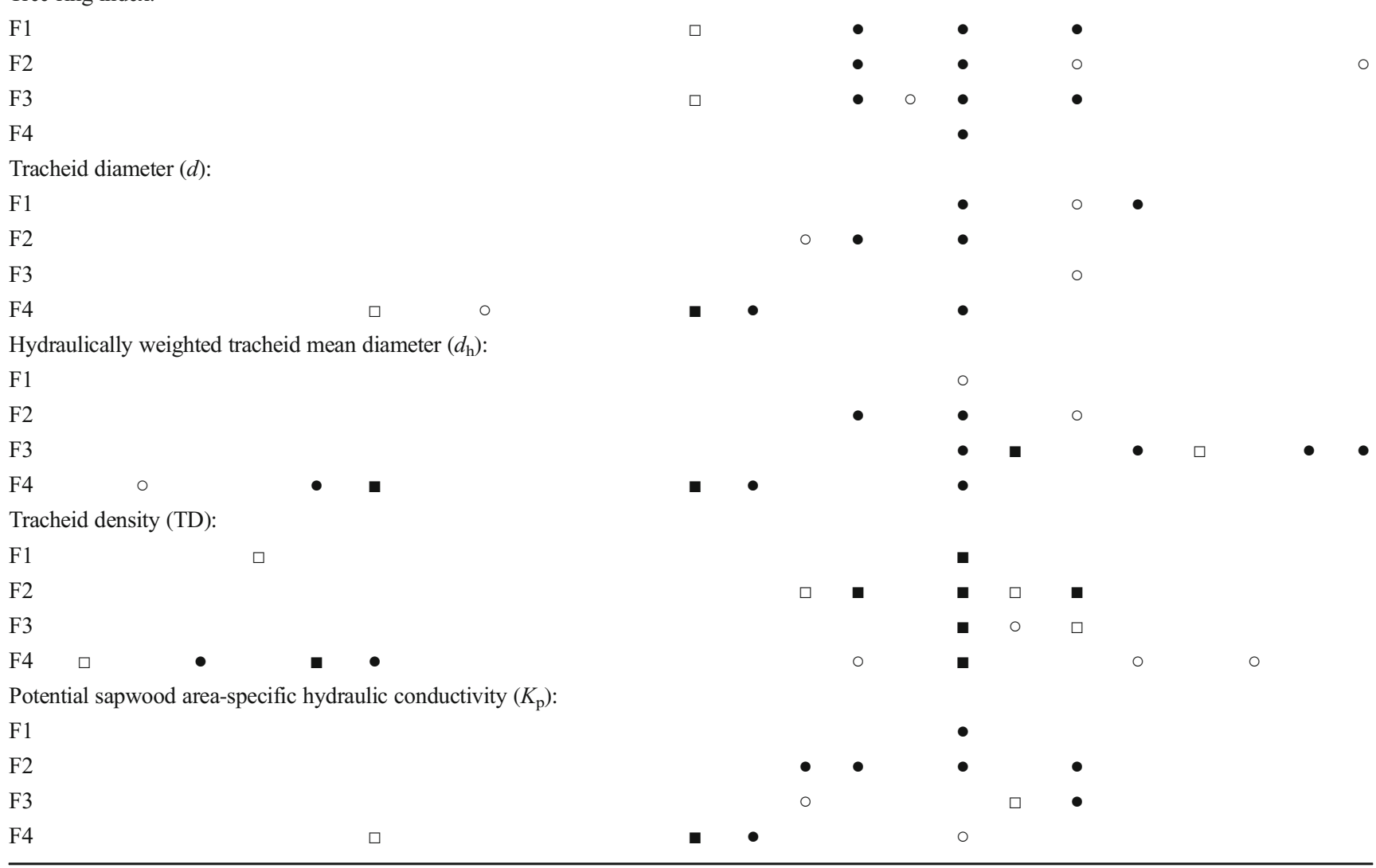

Correlation significant $(P \leq 0.05)$ : • positive, $\square$ negative correlation; marginally significant $(P \leq 0.10)$ : $\circ$ positive, $\square$ negative correlation. Months are identified with numbers 1 to 12 ; months without correlation are not listed 


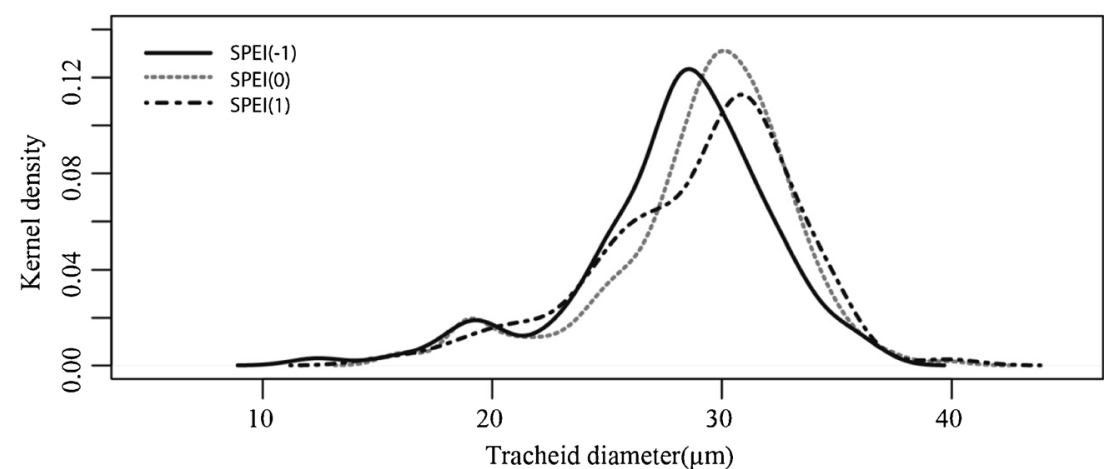

Fig. 4 Density distributions of all tracheid diameters grouped per standardized precipitation-evapotranspiration index (SPEI) of prior year August. Negative and positive SPEI indicate dryness and wetness, respectively. The density distributions were calculated with a Gaussian

highlights the influence of water availability in late summer (Fig. 4). Tracheid diameters were smaller under dry conditions (SPEI-1) than at better water supply (SPEI $\geq 0$ ). Except for $K_{\mathrm{p}}$, which only increased with the previous years' August precipitation in small stands (F1, F2), stand size had no control of the occurrence of correlations between hydraulic traits and climate parameters.

\subsection{Pointer years}

From 1985 to 2014, we found negative pointer years in 1997 and 2008 and positive pointer year in 2006 (Fig. S5). The negative pointer years were associated with low values of $d$,
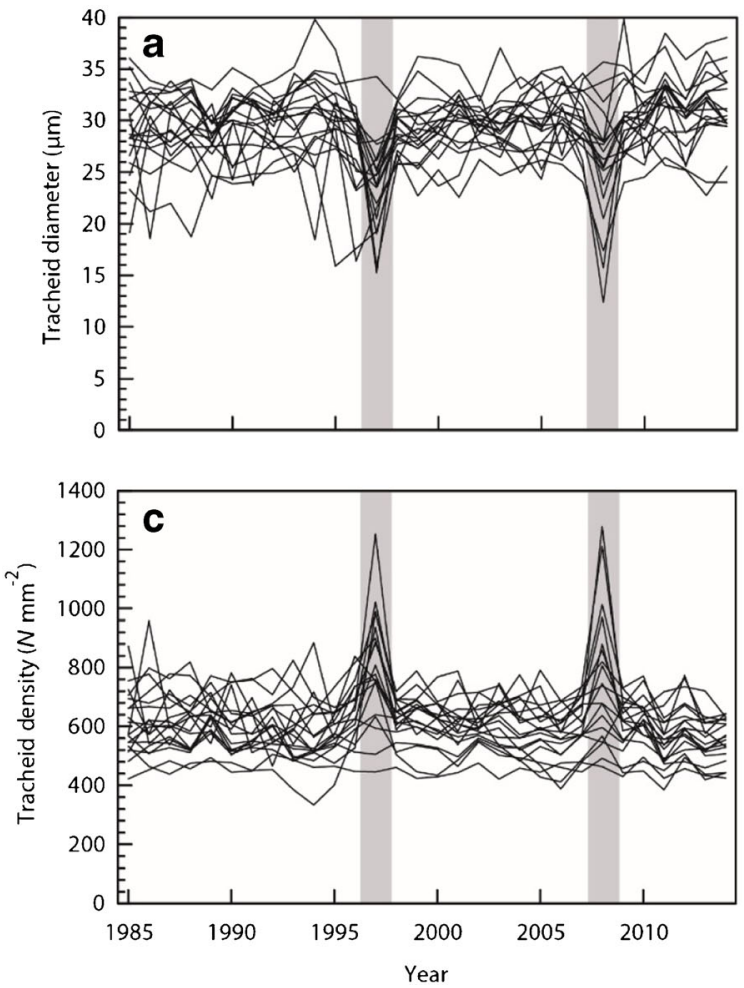

Fig. 5 Time-series of $\mathbf{a} d, \mathbf{b} d_{\mathrm{h}}, \mathbf{c}$ TD, $\mathbf{d} K_{\mathrm{p}}$, over the period 1985-2014. Pointer years 1997 and 2008 are shaded in gray

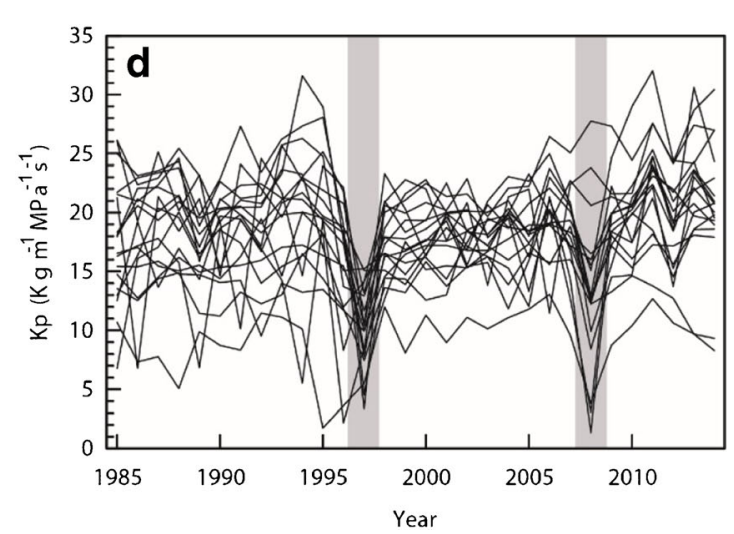

smoothing and the "nrd0" bandwidth using the "density" function of R (R Development Core Team, 2013). Tracheid data from 6, 13, 6 years were included in the classes of SPEI - 1, 0, and 1 respectively. Lines for the SPEI -2 and 2 are not shown since only found in 2 and 3 years

$d_{\mathrm{h}}$, and $K_{\mathrm{p}}$, but high TD (Fig. 5). The pointer year in 1997 followed an intense forest fire in 1996, whereas the pointer year in 2008 followed 2 years with below-average precipitation in August (to, respectively, 35 and $75 \%$ of the mean August precipitation in the period 1985-2014), which was identified as significant for stemwood production in the climate-response analysis (Table 3 ).

\section{Discussion}

Our analyses provide multiple evidence that summer drought in the previous year affects not only tree-ring width, but also

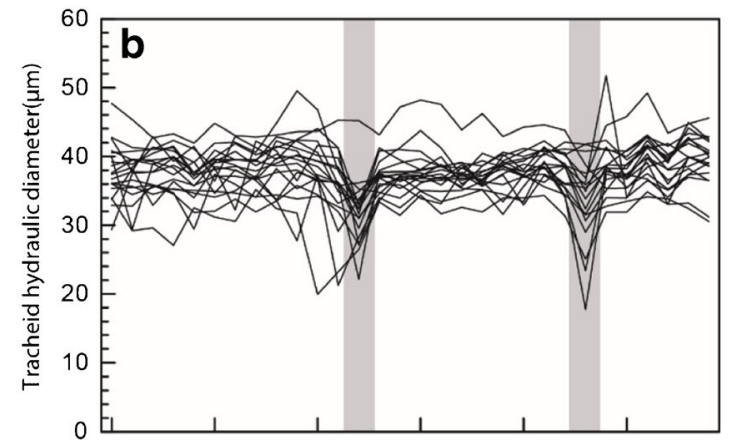


the hydraulic architecture of $L$. sibirica. Tracheid diameters $(d$, $d_{\mathrm{h}}$ ) and the potential sapwood area-specific hydraulic conductivity $\left(K_{\mathrm{p}}\right)$ were strongly reduced due to drought. Climateresponse analysis showed that the amount of precipitation in late summer (August) of the previous year was most influential for determining tracheid diameters and hydraulic conductivity in the consecutive growing season. This relationship coincides with reductions of tree-ring width by drought in the previous growing season that was repeatedly found in water-limited L. sibirica forests (Dulamsuren et al. 2011, 2013; Tei et al. 2017). The influence of the climate in the prior year is often thought (but not proven) to be mediated by the climatic limitation of the tree's capability to build up stocks of non-structural carbohydrates. Carbohydrate reserves from the previous year need to be used, since most wood is formed in the early growing season (Begum et al. 2010). However, the relationships between non-structural carbohydrate pools, climate, and wood formation are complex and far from being completely understood (Oberhuber et al. 2011; Simard et al. 2013; Palacio et al. 2014).

Whether low tracheid diameters are just the consequence of low annual stem increment or can vary independently of each other is not completely clear. There are several examples of reduced conduit diameters at low tree-ring width (Vaganov et al. 2006; Martin-Benito et al. 2013; Ziaco et al. 2014) in agreement with our findings. However, while Khansaritoreh et al. (2017) demonstrated an increasing drought sensitivity of stemwood formation with decreasing forest stand size, we found only loose relations between stand size and hydraulic traits. Although $d, d_{\mathrm{h}}$, and $K_{\mathrm{p}}$ were higher and tracheid density (TD) was lower in the largest forests than in the smallest stands, there was no consistent trend between these parameters and stand size. Moreover, for most parameters, we did not find a consistent change of the relationship of these parameters to climate variables along with forest stand size, in contrast to the observations of Khansaritoreh et al. (2017) for annual stem increment. The only exception was the correlation between $K_{\mathrm{p}}$ and the previous year's August precipitation in the small stands of the size classes F1 and F2, but not in the larger stands (F3, F4). Probably, the more extreme microclimate of the small stands with high maximum temperatures and low humidity increased to responsiveness of $K_{\mathrm{p}}$ to late summer precipitation. We can only speculate why this relationship of stand size with tree-ring width was not more widespread for the woodanatomical and hydraulic parameters. A possible explanation could be the existence of different climatic controls for cell division and cell differentiation. Moreover, it could play a role that we kept tree height constant in the present study, since tracheid diameter is known to be related to tree height, while tree height and diameter are not closely correlated (Anfodillo et al. 2012; Carrer et al. 2015).

The observed reduction of tracheid diameters as the result of summer drought is beneficial for the trees to prevent hydraulic failure and potentially mortality (Sperry et al. 2006; McDowell 2011; Sevanto et al. 2014). Combined with low tracheid density, the formation of low-diameter tracheid reduces hydraulic conductivity. L. sibirica is also known for low fine-root mass during drought (Chenlemuge et al. 2013), providing evidence of low capacity for water transport right from the beginning of the plant's hydraulic pathway as the consequence of preceding drought events. Unfortunately, we have no reliable data of defoliation events and thus Huber values available for $L$. sibirica to quantify the sapwood-toleaf area ratio (Carter and White 2009), which would be helpful for a complete understanding of the drought response in this species. A reduction of transpiration by needle abscission and the closure of stomata would be a likely strategy to form drought resistance in addition to acclimations of the root system (Chenlemuge et al. 2013) and the stem xylem (this study). Studying sites of different macroclimate or competition, Chenlemuge et al. $(2015 \mathrm{a}, \mathrm{b})$ found increasing tracheid diameter and hydraulic conductivity with increasing water availability in root, stem, and branch xylem of $L$. sibirica. Stomatal regulation is generally sensitive in conifers, but less sensitive in L. sibirica than in Pinus sylvestris, which is another drought-tolerant tree species at the southern edge of the boreal forest (Dulamsuren et al. 2009a, b).

\section{Conclusion}

Tracheid diameters $\left(d, d_{\mathrm{h}}\right)$, potential sapwood area-specific hydraulic conductivity $\left(K_{\mathrm{p}}\right)$, and tracheid density (TD) were shown to vary in $L$. sibirica from the Mongolian forest steppe ecotone with temporal variations in climate. In agreement with our first hypothesis, drought in the previous years' late summer reduced tracheid diameters and hydraulic conductivity, but increased tracheid density in the following growing season. Tree-ring width that was shown earlier also to be reduced by summer drought in the preceding year was correlated with tracheid diameter in support of our second hypotheses. Forest fragmentation and the resulting variation in stand climate are apparently only a weak determinant of the hydraulic architecture in L. sibirica, which largely falsifies our third hypothesis. Our findings on the influence of dry late summers on the hydraulic traits in L. sibirica clearly suggest that the trend for increasing summer drought that is observed at the southern fringe of the boreal forest in Inner Asia not only leads to reduced stemwood formation, but also to acclimations of the hydraulic architecture of $L$. sibirica. These acclimations might ensure some protection against hydraulic failure and tree mortality, but reported cases of $L$. sibirica mortality in this region (Liu et al. 2013; Dulamsuren et al. unpublished) demonstrate that this acclimation of the hydraulic system is not capable of keeping pace with the rapid increase in aridity in Inner Asia. 
Acknowledgments The study was supported by a grant of the Volkswagen Foundation to M. Hauck, Ch. Dulamsuren and Ch. Leuschner for the project "Forest regeneration and biodiversity at the forest-steppe border of the Altai and Khangai Mountains under contrasting developments of livestock numbers in Kazakhstan and Mongolia”. E. Khansitoreh received an Erasmus Mundus Scholarship in the Salam 2 program. We are thankful to the director of the Tarvagatai Nuruu National Park, Ms. D. Tuya, for her support during field work.

Funding The study was supported by a grant of the Volkswagen Foundation to M. Hauck, Ch. Dulamsuren and Ch. Leuschner for the project "Forest regeneration and biodiversity at the forest-steppe border of the Altai and Khangai Mountains under contrasting developments of livestock numbers in Kazakhstan and Mongolia” (grant no. I/87 175).

\section{Compliance with ethical standards}

Conflict of interest The authors declare that they have no conflict of interest.

Data availability The datasets generated during and/or analyzed during the current study are available from the corresponding author on reasonable request.

\section{References}

Anfodillo T, Deslauriers A, Menardi R, Tedoldi L, Petit G, Rossi S (2012) Widening of xylem conduits in a conifer tree depends on the longer time of cell expansion downwards along the stem. J Exp Bot 63: 837-845. https://doi.org/10.1093/jxb/err309

Anfodillo T, Petit G, Crivellaro A (2013) Axial conduit widening in woody species: a still neglected anatomical pattern. IAWA J 34: 352-364. https://doi.org/10.1163/22941932-00000030

Begum S, Nakaba S, Oribe Y, Kubo T, Funada R (2010) Changes in the localization and levels of starch and lipids in cambium and phloem during cambial reactivation by artificial heating of main stems of Cryptomeria japonica trees. Ann Bot 106:885-895. https://doi.org/ 10.1093/aob/mcq185

Bryukhanova M, Fonti P (2013) Xylem plasticity allows rapid hydraulic adjustment to annual climatic variability. Trees 27:485-496. https:// doi.org/10.1007/s00468-012-0802-8

Buermann W, Parida B, Jung M, MacDonald GM, Tucker CJ, Reichstein M (2014) Recent shift in Eurasian boreal forest greening response may be associated with warmer and drier summers. Geophys Res Lett 41:1995-2002. https://doi.org/10.1002/2014GL059450

Bunn AG (2008) A dendrochronology program library in R (dplR). Dendrochronologia 26:115-124. https://doi.org/10.1016/j.dendro. 2008.01.002

Carrer M, Von Arx G, Castagneri D, Petit G (2015) Distilling allometric and environmental information from time series of conduit size: the standardization issue and its relationship to tree hydraulic architecture. Tree Physiol 35:27-33. https://doi.org/10.1093/treephys/ tpu108

Carter JL, White DA (2009) Plasticity in the Huber value contributes to homeostasis in leaf water relations of a mallee eucalypt with variation to groundwater depth. Tree Physiol 29:1407-1418. https://doi. org/10.1093/treephys/tpp076

Chenlemuge Ts, Dulamsuren Ch, Hertel D, Schuldt B, Leuschner C, Hauck M (2015a) Hydraulic properties and fine root mass of Larix sibirica along forest edge-interior gradients. Acta Oecol 63:28-35

Chenlemuge Ts, Hertel D, Dulamsuren Ch, Khishigjargal M, Leuschner C, Hauck M (2013) Extremely low fine root biomass in Larix sibirica forests at the southern drought limit of the boreal forest. Flora 208:488-496

Chenlemuge Ts, Schuldt B, Dulamsuren Ch, Hertel D, Leuschner C, Hauck M (2015b) Stem increment and hydraulic architecture of a boreal conifer (Larix sibirica) under contrasting macroclimates. Trees 29:623-636. https://doi.org/10.1007/s00468-014-1131-x

Cochard H, Froux F, Mayr S, Coutand C (2004) Xylem wall collapse in water-stressed pine needles. Plant Physiol 134:401-408. https://doi. org/10.1104/pp.103.028357

Cook E, Holmes R (1984) Program ARSTAN user manual. University of Arizona, Tucson, Arizona, Laboratory of Tree-Ring Research

Cook E, Kairiukstis L (1990) Methods of dendrochronology. Springer, Dordrecht. https://doi.org/10.1007/978-94-015-7879-0

D'Arrigo R, Jacoby G, Pederson N, Frank D, Buckley B, Nachin B, Mijiddorj R, Dugarjav C (2000) Monogolian tree-rings, temperature sensitivity and reconstructions of Northern Hemisphere temperature. The Holocene 10:669-672. https://doi.org/10.1191/09596830094926

De Grandpré L, Tardif JC, Hessl A, Pederson N, Conciatori F, Green TR, Oyunsanaa B, Baatarbileg N (2011) Seasonal shift in the climate responses of Pinus sibirica, Pinus sylvestris, and Larix sibirica trees from semi-arid, north-central Mongolia. Can J For Res 41:12421255. https://doi.org/10.1139/x11-051

Delzon S, Douthe C, Sala A, Cohard H (2010) Mechanism of water-stress induced cavitation in conifers: bordered pit structure and function support the hypothesis of seal capillary-seeding. Plant Cell Environ 33:2101-2111. https://doi.org/10.1111/j.1365-3040.2010.02208.x

Domec J-C, Lachenbruch B, Meinzer FC, Woodruff DR, Warren JM, McCulloh KA (2008) Maximum height in a conifer is associated with conflicting requirements for xylem design. Proc Natl Acad Sci U S A 105:12069-12074. https://doi.org/10.1073/pnas.0710418105

Dulamsuren Ch, Hauck M, Bader M, Osokhjargal D, Oyungerel Sh, Nyambayar S, Runge M, Leuschner C (2009a) Water relations and photosynthetic performance in Larix sibirica growing in the foreststeppe ecotone of northern Mongolia. Tree Physiol 29:99-110

Dulamsuren Ch, Hauck M, Bader M, Oyungerel Sh, Osokhjargal D, Nyambayar S, Leuschner C (2009b) The different strategies of Pinus sylvestris and Larix sibirica to deal with summer drought in a northern Mongolian forest-steppe ecotone suggest a future superiority of pine in a warming climate. Can J For Res 39:2520-2528. https://doi.org/10.1139/X09-156

Dulamsuren Ch, Hauck M, Khishigjargal M, Leuschner HH, Leuschner C (2010) Diverging climate trends in Mongolian taiga forests influence growth and regeneration of Larix sibirica. Oecologia 163: 1091-1102. https://doi.org/10.1007/s00442-010-1689-y

Dulamsuren Ch, Hauck M, Leuschner HH, Leuschner C (2011) Climate response of tree-ring width in Larix sibirica growing in the droughtstressed forest-steppe ecotone of northern Mongolia. Ann For Sci 68:275-282. https://doi.org/10.1007/s13595-011-0043-9

Dulamsuren Ch, Khishigjargal M, Leuschner C, Hauck M (2014) Response of tree-ring width to climate warming and selective logging in larch forests of the Mongolian Altai. J Plant Ecol 7:24-38. https://doi.org/10.1093/jpe/rtt019

Dulamsuren Ch, Klinge M, Degener J, Khishigjargal M, Chenlemuge Ts, Bat-Enerel B, Yeruult Yo, Saindovdon D, Ganbaatar Kh, Tsogtbaatar J, Leuschner C, Hauck M (2016) Carbon pool densities and a first estimate of the total carbon pool in the Mongolian foreststeppe. Glob Chang Biol 22:830-844. https://doi.org/10.1111/gcb. 13127

Dulamsuren Ch, Wommelsdorf T, Zhao F, Xue Y, Zhumadilov BZ, Leuschner C, Hauck M (2013) Increased summer temperatures reduce the growth and regeneration of Larix sibirica in southern boreal forests of eastern Kazakhstan. Ecosystems 16:1536-1549. https://doi.org/10.1007/s10021-013-9700-1

Eckstein D, Bauch J (1969) Beitrag zur Rationalisierung eines dendrochronologischen Verfahrens und zur Analyse seiner 
Aussagesicherheit. Forstwiss Centralbatt 88:230-250. https://doi. org/10.1007/BF02741777

Eilmann B, Weber P, Rigling A, Eckstein D (2006) Growth reactions of Pinus sylvestris L. and Quercus pubescens Willd. to drought years at a xeric site in Valais, Switzerland. Dendrochronologia 23:121-132. https://doi.org/10.1016/j.dendro.2005.10.002

Eilmann B, Zweifel R, Buchmann N, Fonti P, Rigling A (2009) Droughtinduced adaptation of the xylem in Scots pine and pubescent oak. Tree Physiol 29:1011-1020. https://doi.org/10.1093/treephys/ tpp035

Fonti P, Babushkina EA (2015) Tracheid anatomical responses to climate in a forest-steppe in southern Siberia. Dendrochronologia 39:32-41

Fritts HC (1976) Tree rings and climate. Academic Press, London

Hacke UG, Sperry JS (2001) Functional and ecologycal xylem anatomy. Perspect Plant Ecol Evol Syst 4:97-115. https://doi.org/10.1078/ 1433-8319-00017

Hacke UG, Sperry JS, Pockman WT, Davis SD, McCulloh KA (2001) Trends in wood density and structure are linked to prevention of xylem implosion by negative pressure. Oecologia 126:457-461. https://doi.org/10.1007/s004420100628

Hansen MC, Potapov PV, Moore R, Hancher M, Turubanova SA, Tyukavina A, Thau D, Stehman SV, Goetz SJ, Loveland TR, Kommareddy A, Egorov A, Chini L, Justice CO, Townshend JRG (2013) High-resolution global maps of 21st-century forest cover change. Science 342:850-853. https://doi.org/10.1126/science. 1244693

IPCC (2013) Climate change 2013: the physical science basis. Contribution of working group I to the fifth assessment report of the Intergovernmental Panel on Climate Change. Cambridge University Press, Cambridge

Jacoby GC, D'Arrigo RD, Davaajamts T (1996) Mongolian tree-rings and 20th-century warming. Science 273:771-773. https://doi.org/10. 1126/science.273.5276.771

Khansaritoreh E, Dulamsuren Ch, Klinge M, Ariunbaatar T, Bat-Enerel B, Batsaikhan G, Ganbaatar Kh, Saindovdon D, Yeruult Yo, Tsogtbaatar J, Tuya D, Leuschner C, Hauck M (2017) Higher climate warming sensitivity of Siberian larch in small than large forest islands in the fragmented Mongolian forest steppe. Glob Chang Biol 23:3675-3689. https://doi.org/10.1111/gcb.13750

Khishigjargal M, Dulamsuren Ch, Lkhagvadorj D, Leuschner C, Hauck M (2013) Contrasting responses of seedling and sapling densities to livestock density in the Mongolian forest-steppe. Plant Ecol 214: 1391-1403. https://doi.org/10.1007/s11258-013-0259-x

Koch GW, Sillett SC, Jennings GM, Davis SD (2004) The limits to tree height. Nature 428:851-854. https://doi.org/10.1038/nature02417

Liu H, Park Williams A, Allen CD, Guo D, Wu X, Anenkhonov OA, Liang E, Sandanov DV, Yin Y, Qi Z, Badmaeva NK (2013) Rapid warming accelerates tree growth decline in semi-arid forests of Inner Asia. Glob Chang Biol 19:2500-2510. https://doi.org/10.1111/gcb. 12217

Lkhagvadorj D, Hauck M, Dulamsuren Ch, Tsogtbaatar J (2013) Pastoral nomadism in the forest-steppe of the Mongolian Altai under a changing economy and a warming climate. J Arid Environ 88:8289. https://doi.org/10.1016/j.jaridenv.2012.07.019

Martin-Benito D, Beeckman H, Cañellas I (2013) Influence of drought on tree rings and tracheid features of Pinus nigra and Pinus sylvestris in a mesic Mediterranean forest. Eur J For Res 132:33-45. https://doi. org/10.1007/s10342-012-0652-3

McDowell NG (2011) Mechanisms linking drought, hydraulics, carbon metabolism, and vegetation mortality. Plant Physiol 155:10511059. https://doi.org/10.1104/pp.110.170704

Oberhuber W, Swidrak I, Pirkebner D, Gruber A (2011) Temporal dynamics of nonstructural carbohydrates and xylem growth in Pinus sylvestris exposed to drought. Can J For Res 41:1590-1597. https:// doi.org/10.1139/x11-084
Palacio S, Hoch G, Sala A, Körner C, Millard P (2014) Does carbon storage limit tree growth? New Phytol 201:1096-1100. https://doi. org/10.1111/nph.12602

Pennisi E (2005) Tree growth: the sky is not the limit. Science 310:18961897. https://doi.org/10.1126/science.310.5756.1896

Pittermann J, Sperry JS, Wheeler JK, Hacke UG, Sikkema EH (2006) Mechanical reinforcement of tracheids compromises the hydraulic efficiency of conifer xylem. Plant Cell Environ 29:1618-1628. https://doi.org/10.1111/j.1365-3040.2006.01539.x

Poyatos R, Aguadé D, Galiano L, Mencuccini M, Martínez-Vilalta J (2013) Drought-induced defoliation and long periods of near-zero gas exchange play a key role in accentuating metabolic decline of Scots pine. New Phytol 200:388-401. https://doi.org/10.1111/nph. 12278

Poyatos R, Martínez-Vilalta J, Čermák J, Ceulemans R, Granier A, Irvine J, Köstner B, Lagergren F, Meiresonne L, Nadezhdina N, Zimmermann R, Llorens P, Mencuccini M (2007) Plasticity in hydraulic architecture of Scots pine across Eurasia. Oecologia 153: 245-259. https://doi.org/10.1007/s00442-007-0740-0

Ryan MG, Phillips N, Bond BJ (2006) The hydraulic limitation hypothesis revisited. Plant Cell Environ 29:367-381. https://doi.org/10. 1111/j.1365-3040.2005.01478.x

Ryan MG, Yoder BJ (1997) Hydraulic limits to tree height and tree growth: what keeps trees from growing beyond a certain height? Bioscience 47:235-242. https://doi.org/10.2307/1313077

Schneider L, Gärtner H (2013) The advantage of using a starch based non-Newtonian fluid to prepare micro sections. Dendrochronologia 31:175-178. https://doi.org/10.1016/j.dendro.2013.04.002

Schweingruber FH, Eckstein D, Serre-Bachet F, Bräker OU (1990) Identification, presentation and interpretation of event years and pointer years in dendrochronology. Dendrochronologia 8:9-38

Sevanto S, Mcdowell NG, Dickman LT, Pangle R, Pockman WT (2014) How do trees die? A test of the hydraulic failure and carbon starvation hypotheses. Plant Cell Environ 37:153-161. https://doi.org/10. 1111/pce. 12141

Simard S, Giovannelli A, Treydte K, Traversi ML, King GM, Frank D, Fonti P (2013) Intra-annual dynamics of non-structural carbohydrates in the cambium of mature conifer trees reflects radial growth demands. Tree Physiol 33:913-923. https://doi.org/10.1093/ treephys/tpt075

Sperry J, Nichols K, Sullivan J, Eastlack S (1994) Xylem embolism in ring-porous, diffuse-porous, and coniferous trees of northern Utah and interior Alaska. Ecology 75:1736-1752. https://doi.org/10. $2307 / 1939633$

Sperry JS, Hacke UG, Pittermann J (2006) Size and function in conifer tracheids and angiosperm vessels. Am J Bot 93:1490-1500. https:// doi.org/10.3732/ajb.93.10.1490

Tei S, Sugimoto A, Yonenobu H, Matsuura Y, Osawa A, Sato H, Fujinuma J, Maximov T (2017) Tree-ring analysis and modeling approaches yield contrary response of circumboreal forest productivity to climate change. Glob Chang Biol 23:5179-5188. https:// doi.org/10.1111/gcb.13780

Thornthwaite CW (1948) An approach toward a rational classification of climate. Geogr Rev 38:55-94. https://doi.org/10.2307/210739

Tsogtbaatar J (2004) Deforestation and reforestation needs in Mongolia. For Ecol Manag 201(1):57-63. https://doi.org/10.1016/j.foreco. 2004.06.011

Tyree MT (2003) Hydraulic limits on tree performance: transpiration, carbon gain and growth of trees. Trees 17:95-100

Tyree MT, Zimmermann MH (2002) Xylem structure and the ascent of sap. Springer, Berlin. https://doi.org/10.1007/978-3-662-04931-0

Vaganov E, Hughes M, Shashkin A (2006) Growth dynamics of conifer tree rings. Springer, Berlin

van der Maaten-Theunissen M, van der Maaten E, Bouriaud O (2015) PointRes: an R package to analyze pointer years and components of 
resilience. Dendrochronologia 35:34-38. https://doi.org/10.1016/j. dendro.2015.05.006

Vicente-Serrano S, Beguería S, López-Moreno J (2010) A multiscalar drought index sensitive to global warming: the standardized precipitation evapotranspiration index. J Clim 23:1696-1718. https://doi. org/10.1175/2009JCLI2909.1

Wang L, Payette S, Bégin Y (2002) Relationships between anatomical and densitometric characteristics of black spruce and summer temperature at tree line in northern Quebec. Can J For Res 32:477-486. https://doi.org/10.1139/x01-208

White F (1991) Viscous fluid flow. MacGraw, New York

Wigley TML, Briffa KR, Jones PD, Wigley TML, Briffa KR, Jones PD (1984) On the average value of correlated time series, with applications in dendroclimatology and hydrometeorology. J Clim Appl
Meteorol 23:201-213. https://doi.org/10.1175/1520-0450(1984) 023<0201:OTAVOC $>2.0 . \mathrm{CO} ; 2$

Woodruff DR, Bond BJ, Meinzer FC (2004) Does turgor limit growth in tall trees? Plant Cell Environ 27:229-236. https://doi.org/10.1111/j. 1365-3040.2003.01141.x

Yasue K, Funada R, Kobayashi O, Ohtani J (2000) The effects of tracheid dimensions on variations in maximum density of Picea glehnii and relationships to climatic factors. Trees 14:223-229. https://doi.org/ 10.1007/PL00009766

Ziaco E, Biondi F, Rossi S, Deslauriers A (2014) Climatic influences on wood anatomy and tree-ring features of Great Basin conifers at a new mountain observatory. Appl Plant Sci 2, . doi: https://doi.org/ 10.3732/apps. 1400054 